DE

M E D I C I N A

T R O P I C A L

$\mathrm{DE}$

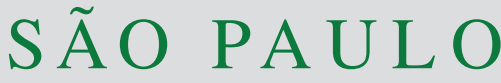

JOURNAL OF THE SÃO PAULO INSTITUTE OF TROPICAL MEDICINE

${ }^{1}$ Secretaria de Estado da Saúde de São Paulo, Superintendência de Controle de Endemias, São Paulo, Brazil

${ }^{2}$ Drugs for Neglected Diseases iniciative (DNDi), Geneva, Switzerland

${ }^{3}$ Secretaria de Estado da Saúde de São Paulo, Centro de Vigilância Epidemiológica, São Paulo, São Paulo, Brazil

${ }^{4}$ Universidade de São Paulo, Instituto de Medicina Tropical de São Paulo, São Paulo, São Paulo, Brazil

${ }^{5}$ Santa Casa de São Paulo, Faculdade de Ciências Médicas, São Paulo, São Paulo, Brazil

${ }^{6}$ Universidade de São Paulo, Faculdade de Medicina, Departamento de Moléstias Infecciosas e Parasitárias, Laboratório de Investigação Médica em Imunologia (LIM48), São Paulo, São Paulo, Brazil

Correspondence to: Dalva Marli Valério Wanderley

Secretaria de Estado da Saúde de São Paulo, Superintendência de Controle de Endemias, Rua Paula Souza, 166, CEP 01027-000, São Paulo, SP, Brazil

E-mail: dalva.wanderley@gmail.com

Received: 22 November 2019

Accepted: 18 May 2020

\section{Awareness of Chagas disease and socioeconomic characteristics of Bolivian immigrants living in Sao Paulo, Brazil}

\author{
Rubens Antonio da Silva1, Dalva Marli Valério Wanderley ${ }^{\circledR}$, Colin Forsyth ${ }^{2}$, \\ Ruth Moreira Leite ${ }^{3}$, Expedito José de Albuquerque Luna ${ }^{4}$, Nivaldo Carneiro \\ Júnior $^{5}$, Maria Aparecida Shikanai-Yasuda ${ }^{4,6}$
}

\section{ABSTRACT}

In this study which is part of a research project on Chagas disease (CD) among Bolivian immigrants in Sao Paulo, we describe socioeconomic characteristics, knowledge of CD and implications for acess to health care. We applied a structured questionnaire to a sample of 472 Bolivian adults (> 18 years) living in Sao Paulo and enrolled at the Barra Funda School Health Center. Participants' median age was 28.5 years, $75.0 \%$ were from the Bolivian department of La Paz, and $>90 \%$ worked in the garment industry. Respondents had lived in Sao Paulo for a median of 5.8 years. Only 169 (35.8\%) were familiar with CD, while roughly half $(50.4 \%)$ had lived in natural materials houses in Bolivia, $225(47.7 \%)$ indicated familiarity with the vector, $23.9 \%$ had seen the vector in their homes in Bolivia, and $6.4 \%$ reported having been bitten by a triatomine bug. Factors associated with awareness of CD were analyzed by chi square tests, and those with $\mathrm{p}$ values $<0.25$ were included in a multivariable logistic regression model. In the multivariable logistic regression analysis, having a relative with $\mathrm{CD}(\mathrm{OR}=4.3,95 \% \mathrm{CI}=1.5-12.0)$, having lived in a house with mud or wood walls $(\mathrm{OR}=0.4,95 \% \mathrm{CI}=0.2-0.8)$, and having heard of the triatomine bug, or vinchuca, $(\mathrm{OR}=10.0$, $95 \% \mathrm{CI}=5.1-19.5)$ were significantly associated with awareness of CD. This study shows a low familiarity with CD among Bolivian migrants living in Sao Paulo, Brazil. Raising awareness of the disease through specific communication strategies should be an essential component of public health programs to reduce the burden of $\mathrm{CD}$ in this and other vulnerable populations.

KEYWORDS: Bolivian migrants. Chagas disease. Awareness. Healthcare access. Neglected tropical diseases.

\section{INTRODUCTION}

Chagas disease (CD) causes a greater burden of morbimortality than any other parasitic infection in the Americas, yet remains one of the world's most neglected diseases ${ }^{1}$. Although regional collaborations such as the Southern Cone Initiative have led to a tremendous progress in curbing the vector transmission ${ }^{2}$, this success has not been replicated in the healthcarecontext; $<1 \%$ of the over 6 million people living with the disease in the America ${ }^{3}$ have been diagnosed and treated. The intense movement of human populations has been a defining feature of the past three decades and has profoundly impacted the epidemiology of $\mathrm{CD}$, involving nonendemic areas including major urban centers of Latin America ${ }^{4,5}$, Europe and the U.S. ${ }^{6,7}$. The majority of European cases originate from Bolivia, while in the U.S. the highest numbers are from Mexico and Central America. Regional transnational 
migration within Latin America has profoundly impacted CD epidemiology, with implications for public health strategies. For instance, scientific data suggest that Bolivian migrants in Buenos Aires may represent a group with higher risk for $\mathrm{CD}^{8}$.

Migrants with $\mathrm{CD}$ confront unique challenges to accessing the healthcare system; they may possess limited economic resources; be excluded from local healthcare services; and experience difficulties communicating with providers due to linguistic, class and cultural barriers, as seen in Europe and the U.S. ${ }^{9}{ }^{10}$. Despite having a higher risk for $\mathrm{CD}$, immigrants from Latin America are typically undiagnosed and may not have heard of the disease ${ }^{11,12}$. In addition, providers in host countries are often unfamiliar with $\mathrm{CD}$ and not up-to-date with treatment recommendations ${ }^{13,14}$. These many barriers can prevent migrants from having timely acess to diagnosis and etiological treatment.

Brazil exemplifies many of the changing dynamics in CD's social and epidemiological profile. In 2006, the Pan American Health Organization certified the interruption of transmission by the main vector, Triatoma infestans ${ }^{15}$ but estimates suggest there are over one million people infected with $T$. $c r u z i^{2,16}$. Internal migration from endemic rural areas has made $\mathrm{CD}$ a public health challenge in Brazilian cities. Sao Paulo, the fifth largest city in the world, is also a major destination for transnational migration. Over 350,000 Bolivian immigrants live in the city ${ }^{17}$ and a recent seroprevalence study in this population found $4.4 \%$ with T. cruzi infection ${ }^{18}$. Bolivians primarily migrate to Sao Paulo in search of job opportunities and greater economic stability for their families ${ }^{19-21}$. Prior research on Bolivian immigrants living near downtown Sao Paulo indicated a predominantly young population working mainly in garment sweatshops; the majority earning between 1-3 times minimum wage ${ }^{22}$.

In this study, which is part of a larger research project on $\mathrm{CD}$ among Bolivian residents in Sao Paulo, we describe socioeconomic characteristics, awareness of CD and implications for health care in a sample of Bolivian immigrants. The goal is to gain knowledge and insight for strengthening healthcare policies and the delivery of services to help this migrant population overcoming the various barriers to diagnosis and treatment of $\mathrm{CD}$.

\section{METHODS}

A cross-sectional study was carried out through the application of a structured questionnaire to a sample of 472 Bolivian adults ( $>18$ years old) living in Sao Paulo who were registered at the Dr. Alexandre Vranjac Escola Barra Funda Health Center (CSEBF is its Portuguese acronym), a primary care clinic which is part of the Brazilian Public Health System. The sample size was estimated by stratifying the population, considering an estimated $7 \%$ prevalence of Chagas disease in migrant adults and assuming a variability of the estimate of $20 \%$ (95\% confidence interval). The CSEBF, located in the central part of the city, is a reference center for the organization of assistance and care with the specific aim of guaranteeing healthcare access for this population ${ }^{23}$, providing free primary healthcare services to individuals regardless of their immigration status. From July to November 2013, participants were recruited while attending appointments at the CSEBF for various reasons. Participants who agreed to participate in the study underwent an informed consent process in Spanish. Roughly 95\% of the patients who were approached agreed to participate.

The questionnaire was pre-tested and validated, being applied by professionals duly trained for this purpose and fluent in the Spanish language. The investigators created and used a Spanish-language questionnaire with multiple choice questions on sex, age, time living in Sao Paulo, education, income, employment situation and other socioeconomic variables. Participants were also asked about familiarity with the "vinchuca" (the common name for the triatomine bug vector in Bolivia) and with $\mathrm{CD}$, including its transmission and symptoms. Other questions focused on risk factors for $\mathrm{CD}$ and women of childbearing age were asked on theaccess to Brazilian maternal/reproductive health services. After asking for the patients' consent, Spanish-speaking interviewers applied the questionnaire and checked to ensure the respondents' comprehension. All the participants were tested for CD.

Questionnaire data were coded and stored in a database for subsequent analysis. Statistical analyses were performed using the Epidat v. 3.5.1 (Dirección Xeral de Saúde Pública, Galicia, Spain) and the SPSS v. 25.0. (IBM, Armonk, NY, USA). In an initial univariate analysis, we calculated proportions and used chi-square tests to identify factors associated with the awareness of $\mathrm{CD} ; \mathrm{p} \leq 0.05$ was considered significant. We then used a multivariable logistic regression model, including variables with a $\mathrm{p}$ value less than 0.25 in the univariate analysis ${ }^{24}$, to identify variables independently associated with the knowledge of CD.

The study is part of a larger research project entitled "Chagas disease in the Bolivian population of Sao Paulo: an analysis of prevalence of Trypanosoma cruzi infection, morbidity, knowledge, and access to healthcare", which was financed by the National Council for Scientific and Technological Development-Department of Science and Technology CNPq/ DECIT, Ministry of Health, Brazil (grant $\mathrm{N}^{\circ}$ 404336/2012). The Ethics approval was given 
by the Committee of Ethics in Research from the Clinical Hospital of the School of Medicine of the University of Sao Paulo ( ${ }^{\circ}$ 196.698/2013), and written informed consent was requested from all the participants.

\section{RESULTS}

There were slightly more females $(n=255,54 \%)$ than males $(n=217,46 \%)$, and more than half of the respondents fell into the $18-29$ age range, while $<15 \%(n=67)$ were over 40. Three quarters of the respondents $(n=358)$ were born in the Bolivian department of La Paz (Table 1). The median age was 28.5, and participants had lived in Sao Paulo for a median of 5.8 years. Most respondents $(\mathrm{n}=252,53.4 \%)$ had lived in Sao Paulo between 1-5 years, though 209 (44.3\%) indicated $>5$ years' residence. Two thirds of the respondents $(n=320)$ had completed a high school education, though only 22 had continued to college. Nearly all the respondents $(99.0 \%)$ lived in two neighborhoods, Bom Retiro and Barra Funda. Over $90 \%(\mathrm{n}=428)$ worked in the garment industry. While 102 participants (21.6\%) reported a per-person family income of less than 678 BR or 299 US dollars, which was the minimum wage at the time ${ }^{25}, 250(52.9 \%)$ earned between 1-2 times the minimum wage. Neither the time living in Sao Paulo nor the education level were associated with significant differences in the income.

Nearly half $(n=225,47.7 \%)$ of the participants indicated familiarity with the triatomine vector ("vinchuca"); $106(22.5 \%)$ had seen the vinchuca in their homes in Bolivia, and $30(6.4 \%)$ recalled being bitten by a triatomine. In Bolivia, 277 participants $(58 / 7 \%)$ had lived in the rural area and $209(44.3 \%)$ had worked in the rural area. Additionally, slightly over half of the respondents $(n=238$, $50.4 \%$ ) had lived in houses made of natural materials (mud or wood). When asked if they knew what CD is, only 169 participants $(35.8 \%)$ responded affirmatively. Of these, $119(70.4 \%)$ claimed that the disease was transmitted by a triatomine insect (known in Bolivia as the vinchuca), but only $26(15.4 \%)$ recognized the "enlargement of the heart" as a potential sign of $\mathrm{CD}$.

We assessed the awareness of $\mathrm{CD}$ and its association with demographic variables and known risk factors (Table 2). Male gender, being born outside the department of $\mathrm{La} \mathrm{Paz}$, having a relative with $\mathrm{CD}$, not having lived in a house with mud or wood walls, having heard of the vinchuca, and having seen or been bitten by a vinchuca were all significantly associated with the awareness of CD in the univariate analysis. We included all the variables with a p value $<0.25$ in the univariate analysis in a multivariable logistic regression model (Table 3). Having a relative with $\mathrm{CD}(\mathrm{OR}=4.3 ; 95 \% \mathrm{CI}=1.5-12.0 \mathrm{p}=0.006)$, having lived in a
Table 1 - Sociodemographic characteristics of participants $(\mathrm{N}=472)$, study of Chagas disease $(C D)$ awareness among Bolivian migrants in Sao Paulo.

\begin{tabular}{|c|c|c|}
\hline Category & $\mathrm{N}$ & $\%$ \\
\hline \multicolumn{3}{|l|}{ Sex } \\
\hline M & 217 & 45.9 \\
\hline $\mathrm{F}$ & 255 & 54.1 \\
\hline \multicolumn{3}{|l|}{ Age group (years) } \\
\hline $18-29$ & 251 & 53.2 \\
\hline $30-39$ & 154 & 32.6 \\
\hline$>40$ & 67 & 14.2 \\
\hline \multicolumn{3}{|l|}{ Residence in São Paulo (years) } \\
\hline$<1$ & 11 & 2.3 \\
\hline $1-5$ & 252 & 53.4 \\
\hline$>5$ & 209 & 44.3 \\
\hline \multicolumn{3}{|l|}{ Lives with } \\
\hline Family & 216 & 45.8 \\
\hline Relatives & 135 & 28.6 \\
\hline Friends & 106 & 22.4 \\
\hline Other & 15 & 3.2 \\
\hline \multicolumn{3}{|l|}{ Marital status } \\
\hline Single & 143 & 30.2 \\
\hline Married & 155 & 32.8 \\
\hline Stable relationship & 161 & 34.1 \\
\hline Other & 13 & 2.9 \\
\hline \multicolumn{3}{|l|}{ Occupation } \\
\hline Garment industry & 428 & 90.6 \\
\hline Other & 44 & 9.4 \\
\hline \multicolumn{3}{|l|}{ Family income } \\
\hline$\leq 1$ minimum salary & 102 & 21.6 \\
\hline $1-2$ times the minimum salary & 250 & 52.9 \\
\hline$>2$ times the minimum salary & 120 & 25.5 \\
\hline \multicolumn{3}{|l|}{ Education level } \\
\hline Primary or less & 15 & 3.2 \\
\hline Some secondary & 137 & 29.0 \\
\hline High school graduate & 298 & 63.1 \\
\hline College & 22 & 4.7 \\
\hline \multicolumn{3}{|l|}{ Risk factors to CD } \\
\hline Recalls being bitten by a "vinchuca" & 30 & 6.4 \\
\hline Recalls vinchucas in the home & 106 & 22.5 \\
\hline Lived in a house of mud or wood & 238 & 50.4 \\
\hline Has a relative with Chagas disease & 48 & 11.7 \\
\hline Lived in a rural area of Bolivia & 277 & 58.7 \\
\hline Worked in a rural area of Bolivia & 209 & 44.3 \\
\hline \multicolumn{3}{|l|}{ Chagas disease awareness } \\
\hline Knows the vector ("vinchuca") & 225 & 47.7 \\
\hline Knows of Chagas disease & 169 & 35.8 \\
\hline Transmitted by triatomines ("vinchucas") & 119 & $70.4^{*}$ \\
\hline May cause enlargement of the heart & 26 & $15.4^{*}$ \\
\hline
\end{tabular}

*percentage within those who know about Chagas disease $(n=169)$ 
Table 2 - Awareness of Chagas disease (CD) in Bolivian migrants in Sao Paulo.

\begin{tabular}{|c|c|c|c|c|c|}
\hline Variable & $\begin{array}{c}\text { Aware of CD } \\
(\mathrm{N}=169) \\
\mathrm{N}(\%)\end{array}$ & $\begin{array}{l}\text { Not aware of CD } \\
\qquad(\mathrm{N}=303)\end{array}$ & $\begin{array}{c}\% \text { aware in } \\
\text { category }\end{array}$ & $\begin{array}{l}\text { Odds Ratio } \\
(95 \% \mathrm{Cl})\end{array}$ & $P$ value \\
\hline \multicolumn{6}{|l|}{ Sex } \\
\hline female & $78 / 169$ (46.2) & $177 / 303(58.4)$ & 30.6 & $0.61(0.42-0.89)$ & 0.010 \\
\hline male & $91 / 169(53.8)$ & $126 / 303(41.6)$ & 41.9 & & \\
\hline \multicolumn{6}{|l|}{ Age (years) } \\
\hline$\geq 30$ & $87 / 169$ (51.5) & $134 / 303(44.2)$ & 39.4 & $1.34(0.92-1.95)$ & 0.130 \\
\hline$<30$ & $82 / 169$ (48.5) & $169 / 303(55.8)$ & 32.7 & & \\
\hline \multicolumn{6}{|l|}{ Department of birth } \\
\hline La Paz & 109/169 (64.5) & 249/303 (82.2) & 30.4 & $0.39(0.26-0.61)$ & $<0.001$ \\
\hline other & 60/169 (35.5) & $54 / 303(17.8)$ & 52.6 & & \\
\hline \multicolumn{6}{|l|}{ Education } \\
\hline high school graduate & 123/169 (72.8) & 197/303 (65.0) & 38.4 & $1.44(0.952-2.17)$ & 0.083 \\
\hline$<$ high school & 46/169 (27.2) & 106/303 (35.0) & 30.3 & & \\
\hline \multicolumn{6}{|l|}{ Lived in rural Bolivia* } \\
\hline Yes & 100/169 (59.2) & 177/299 (59.2) & 36.1 & $1.01(0.69-1.49)$ & 0.945 \\
\hline No & $69 / 169(40.8)$ & $122 / 299(40.8)$ & 35.8 & & \\
\hline \multicolumn{6}{|l|}{ Worked in rural Bolivia* } \\
\hline Yes & $74 / 164(45.1)$ & $135 / 299(45.2)$ & 35.4 & $1.00(0.68-1.47)$ & 0.995 \\
\hline No & $90 / 164$ (54.9) & $164 / 299(54.8)$ & 35.4 & & \\
\hline \multicolumn{6}{|l|}{ Have a relative with CD } \\
\hline Yes & $36 / 169$ (21.3) & $13 / 303(4.3)$ & 72.9 & $5.23(2.67-10.25)$ & $<0.001$ \\
\hline No & 123/169 (72.8) & 239/303 (78.9) & 34.0 & & \\
\hline Don't know & 10/169 (5.9) & $51 / 303(16.8)$ & 17.7 & & \\
\hline \multicolumn{6}{|c|}{ Received a blood transfusion } \\
\hline Yes & $11 / 169(6.5)$ & 16/303 (5.3) & 40.7 & $1.25(0.57-2.76)$ & 0.582 \\
\hline No & $158 / 169(93.5)$ & 287/303 (94.7) & 35.5 & & \\
\hline \multicolumn{6}{|c|}{ Type of housing in Bolivia } \\
\hline Mud or wood & $71 / 169(42.0)$ & 167/303 (55.1) & 29.8 & $0.59(0.40-0.86)$ & 0.006 \\
\hline Brick/cement & 98/169 (58.0) & $136 / 303(44.9)$ & 41.9 & & \\
\hline \multicolumn{6}{|c|}{ Knows the triatomine vector (vinchuca) } \\
\hline Yes & 140/169 (82.8) & $85 / 303(28.1)$ & 62.2 & $12.38(7.72-19.85)$ & $<0.001$ \\
\hline No & 29/169 (17.2) & 218/303 (71.9) & 11.7 & & \\
\hline \multicolumn{6}{|c|}{ Saw a triatomine in the home } \\
\hline Yes & $71 / 169(42.0)$ & $35 / 303(11.6)$ & 67.0 & $5.55(3.48-8.84)$ & $<0.001$ \\
\hline No & 85/169 (50.3)) & $185 / 303(61.0)$ & 31.5 & & \\
\hline Don't know & $13 / 169(7.7)$ & $83 / 303(27.4)$ & 13.5 & & \\
\hline \multicolumn{6}{|c|}{ Remembers being bitten by a vinchuca } \\
\hline Yes & $21 / 169(12.4)$ & 9/303 (3.0) & 70.0 & $4.00(1.77-9.06)$ & $<0.001$ \\
\hline No & 105/169 (62.2) & $180 / 303(59.4)$ & 36.8 & & \\
\hline Don't know & 43/169 (25.4) & 114/303 (37.6) & 27.4 & & \\
\hline \multicolumn{6}{|l|}{ Went hunting in Bolivia } \\
\hline Yes & $56 / 169(33.1)$ & 119/303 (39.3) & 32.0 & $0.77(0.52-1.14)$ & 0.186 \\
\hline No & 113/169 (66.9) & $184 / 303(60.7)$ & 38.0 & & \\
\hline \multicolumn{6}{|l|}{ Handled game in Bolivia } \\
\hline Yes & 63/169 (37.3) & $126 / 303(41.6)$ & 33.3 & $0.84(0.57-1.23)$ & 0.360 \\
\hline No & $106 / 169(62.7)$ & 177/303 (58.4) & 37.5 & & \\
\hline
\end{tabular}


Table 3 - Multivariable logistic regression of factors associated with awareness of Chagas disease.

\begin{tabular}{lcc}
\hline Variable & $\begin{array}{c}\text { Strength of } \\
\text { association } \\
\text { (confidence } \\
\text { interval) }\end{array}$ & p value \\
\hline Female sex & $0.7(0.4-1.3)$ & 0.284 \\
Age $>30$ years & $1.7(0.9-3.1)$ & 0.100 \\
High school education & $1.0(0.5-2.0)$ & 0.954 \\
Relative with Chagas disease & $4.3(1.5-12.0)$ & 0.006 \\
Born in La Paz & $1.0(0.5-2.2)$ & 0.970 \\
Lived in a mud or wood house & $0.4(0.2-0.8)$ & 0.005 \\
Went hunting & $0.7(0.3-1.3)$ & 0.250 \\
Recalls triatomine in home & $0.7(0.4-1.2)$ & 0.170 \\
Recalls triatomine bite & $1.5(0.5-4.2)$ & 0.452 \\
Has heard of the triatomine vector & $10.0(5.1-19.5)$ & $<0.001$ \\
\hline
\end{tabular}

house with mud or wood walls $(\mathrm{OR}=0.4 ; 95 \% \mathrm{CI}=0.2-0.8$, $\mathrm{p}=0.005)$, and having heard of the triatomine vector ("vinchuca") $(\mathrm{OR}=10 ; 95 \% \mathrm{CI}=5.1-19.5, \mathrm{p}<0.001)$ were significantly associated with the awareness of CD (Table 3 ).

Nineteen of twenty-five participants with positive serology for $T$. cruzi were female; the total CD prevalence in this sample was $5.3 \%$. Four of the seropositive individuals had previously donated blood (two in Bolivia, one in Brazil, and one did not indicatethe place), whereas one had received a blood transfusion. Of the 255 females in the sample, only $31(12.2 \%)$ were 40 or older, $246(96.5 \%)$ were of childbearing age (10-49 years old) and 199 (78\%) had children. While $73.7 \%$ of the mothers had received prenatal care $(71.8 \%$ in Brazil and $26.6 \%$ in Bolivia), in only $5.3 \%$ of these cases the CD testing was included, and only $1.5 \%$ informed that their infants had been tested for CD. Of the women who had had prenatalcare, $>90 \%$ were aware of and had used the Brazilian Unified Health System (SUS) for this service; $1.5 \%$ had coverage of private insurances and $2.6 \%$ paid for medical care.

\section{DISCUSSION}

The epidemiology of $\mathrm{CD}$ in the twenty first century has been framed in part by the social and economic forces driving globalization ${ }^{4,5}$. Our study provides insight on South-South migration, which has important implications for the distribution of $\mathrm{CD}$ and access to healthcare. Of note, awareness of $\mathrm{CD}$ in at-risk populations and its importance for health care have rarely been considered in Brazil. The majority of respondents were not familiar with $\mathrm{CD}$. Nonetheless, the prevalence of CD in the sample was $5.3 \%$, and many had been exposed to risk factors including triatomines and/or housing susceptible to triatomine infestation, as was discussed in an earlier report ${ }^{18}$. In our study, the multivariable analysis indicated a significantly lower awareness among people who had lived in houses with mud or wood walls. Nonetheless, this group may be at higher risk for CD. A study in Santa Cruz, Bolivia documented a higher risk for $\mathrm{CD}^{26}$ among patients with cardiomyopathy who had lived in houses with mud or wood walls. In our study, patients with a history of residing in houses of mud or wood may have had lower access to health information and education on $\mathrm{CD}$, resulting in a lower awareness.

Salm and Gertsch surveyed 480 participants from different regions of Bolivia, members of indigenous groups (the majority from Ayoreo, Guarani, Quechua, and Chiquitano communities), while $31.4 \%$ were from major cities (La Paz and Santa Cruz de La Sierra). In these urban centers, the distribution by sex and age and the educational level were similar to our sample. The authors found that $88.5 \%$ of all the participants were familiar with CD, although awareness was the lowest among respondents from La Paz $(74.2 \%)^{27}$. The authors have also indicated that Quechua and Ayoreo respondents were less familiar with transmission routes than Guarani and Chiquitano participants. In our study, knowledge of the vector was the strongest predictor of knowledge of CD. Similarly, Salm and Gertsch found that awareness of CD was strongly associated with the vector in Bolivia.

Other studies have noted varying levels of CD awareness among different immigrant populations. Ramos et al. ${ }^{28}$ colleagues found that $63 \%$ of Bolivian immigrants in a sample in Elche, Spain, had heard of CD. In another study in Valencia, Spain, of 96 Bolivian immigrants, $73(76 \%)$ had some awareness of CD, and most recognized that $\mathrm{CD}$ has an asymptomatic phase ${ }^{29}$. In a sample of 43 Bolivians in Munich, Germany, 30 (69.8\%) indicated they had previously received information about CD, but the majority considered they had limited familiarity with transmission and symptoms, and $>90 \%$ had not been previously tested ${ }^{30}$.

Bolivians in our sample exhibited lower familiarity with CD than in these studies. This could be explained by the respondents' relative youth, perhaps because the household vector transmission in many parts of Bolivia was under control early in the millenia ${ }^{31}$. By comparison, knowledge of CD was significantly higher in older individuals among Bolivians in Valencia ${ }^{29}$. Another possibility is that the bulk of respondents in our study were from La Paz, which has lower levels of CD compared to other departments and was certified free of domiciliary vector transmission by Triatoma infestans ${ }^{32}$. 
Awareness appears to be lower in North American migrants. In a sample of Latin American immigrants in Los Angeles, most of whom were from Mexico and Central America, only $14 \%$ had previously heard of $\mathrm{CD}^{11}$. Similarly, in a sample of migrants at the Guatemala-Mexico border, $80 \%$ had not previously heard of $\mathrm{CD}^{12}$.

Twenty-five participants had positive serology for T. cruzi, as was reported in a previous article ${ }^{18}$, which found that seropositive respondents were significantly more likely to have knowledge of $\mathrm{CD}$ and the vector. Most testing positive were females, yet only $5.3 \%$ of mothers had received CD testing as part of their prenatal care. Four of the seropositive individuals indicated they had previously donated blood, whereas one had received a blood transfusion. Of the four donors, two indicated they had given blood in Bolivia and one in Brazil (the fourth did not specify the location).

Importantly, low awareness is one of numerous barriers impacting the access to diagnosis and treatment for immigrants and other groups afflicted by CD. Awareness can only be understood and addressed in terms of its interrelationship with socioeconomic inequalities, gaps in the public health response to $\mathrm{CD}$ (often a function of political decisions impacting public funding and concerning the populations and health issues to be prioritized), and navigation of cultural and linguistic differences. Farmer ${ }^{33}$ points out that entrenched global political and economic structures largely shape the disease epidemiology; vulnerable groups who bear the heaviest burden and also have the least access to healthcare resources and the strongest limitations on their agency. Sao Paulo has attracted large numbers of migrants in search of employment; this population faces significant barriers to accessing healthcare ${ }^{34-36}$. Bolivians in Sao Paulo are primarily young, and while most have attained a high school education, their income level remains low. Concentrated in Sao Paulo's garment industry, they often confront difficult living and working conditions ${ }^{35,36}$, which exacerbate health risks, especially for tuberculosis and other infectious diseases ${ }^{34}$. Moreover, awareness of $\mathrm{CD}$ is also a key concern within the local health system; vector transmission was interrupted in the Sao Paulo State in the late $1960 \mathrm{~s}^{15,37}$, and many providers in the SUS are unfamiliar with $\mathrm{CD}^{38}$. While Bolivians are a population at particular risk of $\mathrm{CD}$, systematic screening, even for women during prenatal care, is not widely implemented. In our study, only $5.3 \%$ of women received CD screening as part of their prenatal care, which represents a missed opportunity to halt the vertical transmission and prevent a lifelong disease. Furthermore, the bulk of our sample was under the age of 40 , and could therefore still benefit, if seropositive, from a timely etiological treatment to prevent future complications of chronic CD. Such treatment also acts as an effective means of eliminating the vertical transmission ${ }^{8,39,40}$.

Our study has some limitations. The individuals interviewed were attending the CSEBF, and may not reflect the wider Bolivian community in Sao Paulo or elsewhere in Brazil, in particular those individuals who do not frequently attend healthcare services. The CSEBF has a history of working with the Bolivian community and has developed expertise in the health needs of this population, but this could have influenced respondents' perceptions regarding the healthcare access in Brazil. Additionally, we only asked respondents if they knew about Chagas disease and certain aspects of its etiology and symptomology. Our study largely does not assess whether patient concepts of the disease differ from the biomedical model. A prior research in Bolivia suggests people with $\mathrm{CD}$ essentially adopt a biomedical understanding of the disease, but may use alternative approaches to treatment, including ethnomedical remedies ${ }^{41}$. Another potential bias is that because our sample consisted of migrants predominantly under the age of 40 , it might be healthier than the population at large and potentially less concerned about $\mathrm{CD}$, whose chronic symptoms are usually observed in indviduals older than $30^{42}$.

Our study, possibly the first to assess CD knowledge among a transational migrant population in Brazil, indicates that the awareness of CD in this at-risk group is low. This, in combination with limited discussion of $\mathrm{CD}$ in education campaigns or mass media, serves to suppress patient-driven demand for screening, underscoring the importance of both, more intensive $\mathrm{CD}$ awareness initiatives directed toward this population, and proactive screening initiated by providers. Simply "getting to know" about CD does not always translate into increased demand for testing and treatment, as people in endemic areas with difficult access to healthcare have often adapted a strategy of normalizing or naturalizing the existence of $\mathrm{CD}$ as a coping strategy $\mathrm{y}^{27,43,44}$. Therefore, awareness campaigns need to be linked with a broader framework of actions to improve healthcare access for people at risk of CD.

Recent policy developments in Brazil reinforce the need to develop strong communication strategies to raise awareness of $\mathrm{CD}$ in vulnerable groups ${ }^{45}$. A Clinical Protocol for Diagnosis and Treatment of $\mathrm{CD}$, approved in late $2018^{46}$, provides a specific framework for screening, diagnosing and treating patients, and a national policy of official reporting of chronic CD cases, enacted in early 2020, should serve to reinforce epidemiological surveillance and follow-up of patients. Our study also suggests that familiarity with the vector or with the disease (when it affects relatives) are important drivers of CD awareness within this sample. Education campaigns to improve 
awareness of $\mathrm{CD}$, which are culturally and linguistically tailored to the Bolivian population of Sao Paulo, should be accompanied by intensified training and capacitation of primary care personnel at facilities which see large numbers of Bolivian patients.

Diagnosis of CD can be emotionally devastating and may entail stigmatization or anxiety, which can actually discourage patients from seeking testing. Ideally, healthcare for CD should use a holistic approach, addressing not only the disease, but its social determinants and emotional consequences ${ }^{39}$. Finally, care should be taken to heighten awareness in a way that does not create an unfavorable image or contribute to stigmatization of Bolivians and/or immigrants.

\section{ACKNOWLEDGMENTS}

The authors would like to thank: the members of the "Chagas Disease Research Group: Primary Care and Immigration" Cássio Silveira, Fernando Mussa Abujamnra Aith, Lia Maria Brito da Silva, Noêmia Barbosa Carvalho, Célia Regina Furuchó, Camila G. Satolo, Pedro Albajar-Viñas, Magda Maya Atala, Vera Lúcia Teixeira de Freitas, Rosário Quiroga Ferrufino, Luzia Martinelli, Sonia Regina de Almeida, who contributed to the discussion of the results in some general issues, enriching the paper drafting process guided by the main authors.

\section{AUTHORS' CONTRIBUTIONS}

Conception and design: MASY, RAS, DMVW, RML, EJAL, NCJ; data analyses: RAS, EJAL CF; data interpretation: DMVW, MASY, RAS, CF; drafting and revision of the manuscript for important intellectual content: RAS, DMVW, CF, MASY; final approval: MASY, RAS, DMVW, RML, EJAL, NCJ.

\section{CONFLICT OF INTERESTS}

The authors declare no conflict of interests.

\section{REFERENCES}

1. World Health Organization. Health statistics and information systems: disease burden and mortality estimates: disease burden, 2000-2016. [cited 2020 May 19]. Available from: https://www.who.int/healthinfo/global_burden_disease/ estimates/en/index 1.html

2. World Health Organization. Chagas disease in Latin America: an epidemiological update based on 2010 estimates. Wkly Epidemiol Rec. 2015;90:33-43.
3. Dias JC. Southern Cone Initiative for the elimination of domestic populations of Triatoma infestans and the interruption of transfusional Chagas disease. Historical aspects, present situation, and perspectives. Mem Inst Oswaldo Cruz. 2007;102 Suppl 1:11-8.

4. Briceño-León R. La enfermedad de Chagas en las Américas: una perspectiva de ecosalud. Cad Saude Publica. 2009;25 Suppl 1:S71-82.

5. Schmunis GA, Yadon ZE. Chagas disease: a Latin American health problem becoming a world health problem. Acta Trop. 2010;115:14-21.

6. Basile L, Jansà JM, Carlier Y, Salamanca DD, Angheben A, Bartoloni A, et al. Chagas disease in European countries: the challenge of a surveillance system. Euro Surveill. 2011;16:19968.

7. Manne-Goehler J, Umeh CA, Montgomery SP, Wirtz VJ. Estimating the burden of Chagas disease in the United States. PLoS Negl Trop Dis. 2016;10:e0005033.

8. Moscatelli G, Moroni S, García-Bournissen F, Ballering G, Bisio M, Freilij H, et al. Prevention of congenital Chagas through treatment of girls and women of childbearing age. Mem Inst Oswaldo Cruz. 2015;110:507-9.

9. Jackson Y, Castillo S, Hammond P, Besson M, Brawand-Bron A, Urzola D, et al. Metabolic, mental health, behavioural and socioeconomic characteristics of migrants with Chagas disease in a non-endemic country. Trop Med Int Health. 2012;17:595603.

10. Forsyth CJ, Hernandez S, Flores CA, Roman MF, Nieto JM, Marquez G, et al. "It's like a phantom disease": patient perspectives on access to treatment for Chagas disease in the United States. Am J Trop Med Hyg. 2018;98:735-41.

11. Sanchez DR, Traina MI, Hernandez S, Smer AM, Khamag H, Meymandi SK. Chagas disease awareness among Latin American immigrants living in Los Angeles, California. Am J Trop Med Hyg. 2014;91:915-9.

12. Conners EE, Ordoñez TL, Cordon-Rosales C, Casanueva CF, Miranda SM, Brouwer KC. Chagas disease infection among migrants at the Mexico/Guatemala border. Am J Trop Med Hyg. 2017;97:1134-40.

13. Stimpert KK, Montgomery SP. Physician awareness of Chagas disease, USA. Emerg Infect Dis. 2010;16:871-2.

14. Amstutz-Szalay S. Physician knowledge of Chagas disease in Hispanic immigrants living in Appalachian Ohio. J Racial Ethn Health Disparities. 2017;4:523-8.

15. São Paulo. Secretaria da Saúde. Coordenadoria de Controle de Doenças. Certificação de eliminação de Triatoma infestans do Estado de São Paulo. Bol Epidemiol Paulista 2014;11 Esp:1155.

16. Martins-Melo FR, Ramos Jr AN, Alencar CH, Heukelbach J. Prevalence of Chagas disease in Brazil: a systematic review and meta-analysis. Acta Trop. 2014;130:167-74. 
17. Zanella VG. Imigrantes bolivianas em São Paulo: condições de vida e trabalho. Rev Estud Jurid UNESP. 2015;19:1-20.

18. Luna EJ, Furucho CR, Silva RA, Wanderley DM, Carvalho NB, Satolo CG, et al. Prevalence of Trypanosoma cruzi infection among Bolivian immigrants in the city of São Paulo, Brazil. Mem Inst Oswaldo Cruz. 2017;112:70-4.

19. Freitas PT. Imigração e trabalho: determinantes históricas da formação de um circuito de subcontratação de imigrantes bolivianos para o trabalho em oficinas de costura na cidade de São Paulo. In: Anais do $17^{\circ}$ Encontro Nacional de Estudos Populacionais, ABEP. September 20-24, 2010. Caxambú, Minas Gerais, Brazil. [cited 2020 May 19]. Available from: http://www.abep.org.br/publicacoes/index.php/anais/article/ view/2379

20. Freitas PT. Trajetórias laborais/residenciais dos locais de origem e projeto migratório: a migração boliviana para o setor de confecção da cidade de São Paulo. In: Baeninger R, Dedeca CS, organizadores. Processos migratórios no Estado de São Paulo: estudos temáticos. Campinas: Núcleo de Estudos da População; 2013. p.523-50.

21. Silveira C, Goldberg A, Silva TB, Gomes MH, Martin D. O lugar dos trabalhadores de saúde nas pesquisas sobre processos migratórios internacionais e saúde. Cad Saude Publica. 2016;32:e0063916.

22. Silveira C, Carneiro Junior N, Ribeiro MC, Barata RC. Living conditions and access to health services by Bolivian immigrants in the city of São Paulo, Brazil. Cad Saude Publica. 2013;29:2017-27.

23. Carneiro-Junior N, Andrade MC, Luppi CG, Silveira C. Organização das práticas de saúde equânimes em atenção primária em região metropolitana no contexto dos processos de inclusão e exclusão social. Saude Soc. 2006;15:30-9

24. Zhang Z. Model building strategy for logistic regression: purposeful selection. Ann Transl Med. 2016;4:111.

25. Departmento Intersindical de Estatística e Estudos Socioeconômicos. Política de valorização do salário mínimo: salário mínimo de 2013 será de R\$ 678,00. São Paulo: DIEESE; 2012. [cited 2020 May 19]. Available from: https:// cut.org.br/system/uploads/ck/files/migracao/nt-118-dez-2012salariominimo2013.pdf

26. Hidron AI, Gilman RH, Justiniano J, Blackstock AJ, Lafuente $\mathrm{C}$, Selum W, et al. Chagas cardiomyopathy in the context of the chronic disease transition. PLoS Negl Trop Dis. 2010;4: e688.

27. Salm A, Gertsch J. Cultural perception of triatomine bugs and Chagas disease in Bolivia: a cross-sectional field study. Parasit Vectors. 2019;12:291.

28. Ramos JM, Ponce Y, Gallegos I, Flóres-Chávez M, Cañavate C, Gutiérrez F. Trypanosoma cruzi infection in Elche (Spain): comparison of the seroprevalence in immigrants from Paraguay and Bolivia. Pathog Glob Health. 2012;106:102-6.
29. Salvador-Gil V, Usero-Ruiz AI, Muñoz-Miguel J, Ortí-Lucas RM. Knowledge of Chagas disease in a Bolivian population living in Valencia, Spain. J Epidemiol Res. 2017;3:7-12.

30. Navarro M, Berens-Riha N, Hohnerlein S, Seiringer P, von Saldern C, Garcia S, et al. Cross-sectional, descriptive study of Chagas disease among citizens of Bolivian origin living in Munich, Germany. BMJ Open. 2017;7:e13960.

31. Lardeux F, Depickère S, Aliaga C, Chavez T, Zambrana L. Experimental control of Triatoma infestans in poor rural villages of Bolivia through community participation. Trans $\mathrm{R}$ Soc Trop Med Hyg. 2015;109:150-8.

32. Organización Panamericana de la Salud. Agencia Española de Cooperación Internacional para el Desarrollo. Agencia Canadiense de Desarrollo Internacional. XVIII ${ }^{a}$ Reunion de La Comisión Intergubernamental de la Iniciativa Subregional Cono Sur de Eliminación de Triatoma infestans y la interrupción de la transmissión transfusional de la tripanosomiasis americana: Cochabamba, Bolivia, 27-29 de julio, 2011. Montevideo: OPS; 2011.

33. Farmer P. An anthropology of structural violence. Curr Anthropol. 2004;45:305-25.

34. Freitas PT. Família e inserção laboral de jovens migrantes na indústria de confecção. Rev Interdiscipl Mobil Hum. 2014;22:231-46.

35. Carneiro Junior N, Oliveira RL, Jesus CH, Luppi GG. Migração, exclusão social e serviços de saúde: o caso da população boliviana no centro da cidade de São Paulo. BIS Bol Inst Saude. 2011;13:177-81.

36. Goldberg A, Silveira C. Desigualdad social, condiciones de acceso a la salud pública y procesos de atención en inmigrantes bolivianos de Buenos Aires y São Paulo: una indagación comparativa. Saude Soc. 2013;22:283-97.

37. Silva EO, Rodrigues VL, Silva RA, Wanderley DM. Programa de Controle da Doença de Chagas no estado de São Paulo, Brasil: o controle e a vigilância da transmissão vetorial. Rev Soc Bras Med Trop. 2011;44 Suppl 2:74-84.

38. Carneiro Junior N, Silveira C, Silva LM, Shikanai-Yasuda MA. Migração boliviana e doença de Chagas: limites na atuação do Sistema Único de Saúde brasileiro (SUS). Interface (Botucatu). 2018;22:87-96.

39. Sosa-Estani S, Cura E, Velazquez E, Yampotis C, Segura EL. Etiological treatment of young women infected with Trypanosoma cruzi, and prevention of congenital transmission. Rev Soc Bras Med Trop. 2009;42:484-7.

40. Fabbro DL, Danesi E, Olivera V, Codebó MO, Denner S, Heredia C, et al. Trypanocide treatment of women infected with Trypanosoma cruzi and its effect on preventing congenital Chagas. PLoS Negl Trop Dis. 2014;8:e3312.

41. Oliveira Jr WD. All-around care for patients with Chagas disease: a challenge for the XXI century. Mem Inst Oswaldo Cruz. 2009;104 Suppl 1:181-6. 
42. Forsyth C. Controlled but not cured: structural factors and explanatory models of Chagas disease in tropical Bolivia. Soc Sci Med. 2015;145:7-16.

43. Rassi Jr A, Rassi A, Marin-Neto JA. Chagas disease. Lancet. 2010;375:1388-402.

44. Sanmartino M. ¿Qué es lo primero que piensa cuando escucha la palabra "Chagas"? Rev Salud Publica. 2009;13:74-8.

45. Forsyth CJ. "I cannot be worried": living with Chagas disease in tropical Bolivia. PLoS Negl Trop Dis. 2017;11:e0005251
46. Brasil. Ministério da Saúde. Secretaria de Ciência, Tecnologia e Insumos Estratégicos. Portaria $n^{\circ} 57$, de 30 de outubro de 2018. Torna pública a decisão de aprovar o Protocolo Clínico e Diretrizes Terapêuticas da doença de Chagas, no âmbito do Sistema Único de Saúde - SUS. Diário Oficial da União, Brasilia, 31 Out. 2018. [cited 2020 May 19]. Available from: http://conitec.gov.br/images/PCDT_Doenca_de_Chagas.pdf 